\title{
MATERIAKY, INFORMACJE
}

\section{Bogusław Zakrzewski}

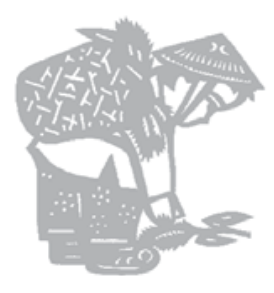

\section{PASJE PROFESORA KOLMAŠA}

Profesor dr Josef Kolmaš, jeden z czołowych europejskich sinologów i tybetologów, o imponującym dorobku i międzynarodowej renomie, urodził się 6 sierpnia 1933 r. w Temici, na południowych Morawach. Uczył się w gimnazjum i mieszkał w internacie prowadzonym przez jezuitów w Velehradzie, gdzie jednym z jego nauczycieli był Tomas Szpidlik, w 2003 r. podniesiony przez Jana Pawła II do godności kardynała. Doskonała znajomość łaciny spowodowała zainteresowanie misjonarską pracą jezuitów w Chinach i Tybecie, prowadzoną od XVII w. Młody Kolmaš wstąpił nawet do nowicjatu w 1948 r., ale w kwietniu 1950 r. służba bezpieczeństwa deportowała członków wspólnoty, poddając ich ,,reedukacji przez pracę". Małoletniego Josefa zwolniono po kilku miesiącach i mógł dokończyć naukę w szkole średniej, gdzie nauczyciel francuskiego rozbudził w nim zainteresowanie językiem chińskim.

W 1952 rozpoczął studia sinologiczne na Uniwersytecie Karola w Pradze u prof. J. Pruška i jego uczniów. Na II roku podjął naukę języka tybetańskiego. W 1957 r. otrzymał dyplom ukończenia studiów, przedkładając pracę o zaniku ambanatu (tj. instytucji rezydenta-namiestnika $\mathrm{z}$ ramienia rządu pekińskiego) w Tybecie z końcem dynastii mandżurskiej (1911).

Przez dwa lata przebywał na podyplomowym studium w Pekinie, głównie w Instytucie Mniejszości Narodowych, gdzie pogłębiał wiedzę na temat języka i kultury tybetańskiej. Do kraju przywiózł ze sobą pełne wydanie tybetańskiego kanonu buddyjskiego bka gyur i bstan gyur. Całe życie zawodowe profesor Kolmaš spędził w Instytucie Orientalistyki Czechosłowackiej, a następnie, Czeskiej Akademii Nauk.

Stopień kandydata nauk uzyskał w 1965 r. - dysertacja nosiła tytuł Konferencja $w$ Simli, 1913-1914. Od maja 1994 do 2002 był kierownikiem wspomniane- 
go Instytutu. Poczynając od wczesnych lat 90. wykładał także na uniwersytecie w Brnie, gdzie habilitował się w dziedzinie antropologii kulturowej (Antropologicke struktury zemi vychodni a vnitrni Asie a jeich misto v soucasnem svete: Fenomen sociokulturniho prenosu), gdzie uzyskał tytuł profesora.

W ciągu niemal 50 lat uczestniczył, wygłaszając referaty, w licznych naukowych konferencjach międzynarodowych w wielu krajach Europy, Azji, Ameryki i Oceanii; odwiedzał je także podczas pobytów naukowych i wykładów. Jest członkiem International Association for Tibetan Studies (1979), European Association of Chinese Studies (1990) i in. Współpracuje z zagranicznymi czasopismami naukowymi, zajmującymi się problematyką Azji Wschodniej.

Wydany w 1999 r. w Pradze drukiem przez Instytut Orientalistyczny spis publikowanych i niepublikowanych prac J. Kolmaša obejmuje ponad 700 pozycji różnego rodzaju - tekstów własnych i przekładów z chińskiego, tybetańskiego, angielskiego, francuskiego, rosyjskiego.

$\mathrm{Na}$ temat dokonań uczonego pisali różni autorzy - jednym z nich jest Martin Slobodnik, którego artukuł Naukowa droga sinologiczno-tybetańska - na jubileusz (70-lecie) profesora Josefa Kolmaša znalazł się w numerze drugim (2003) czasopopisma „Studia Orientalia Slovaka”, wydawanego przez Katedrę Języków i Kultur Krajów Azji Wschodniej Wydziału Filozoficznego Uniwersytetu im. A. Komeńskiego w Bratysławie.

Wybrane prace w jęz. angielskim prof. Josefa Kolmaša:

1. Tibet and imperial China; a survey of Sino-Tibetan relations up to the end of the Manchu dynasty in 1912, Canberra 1967.

2. Genealogy of the Kings of Derge (Sde-dge'i rgyal rabs). Tibetan text edited with historical introduction by Josef Kolmaš, Prague 1968.

3. Tibetan manuscripts and blockprints in the Library of the Oriental Institute Prague, Prague 1969.

4. Prague collection of Tibetan prints from Derge; a facsimile reproduction of 5,615 book-titles printed at the dGon-chen and dPal-spungs monasteries of Derge in Eastern Tibet, Wiesbaden-Prague 1971-1996.

5. Iconography of the Derge Kanjur and Tanjur: facsimile reproductions of the 648 illustrations in the Derge edition of the Tibetan Tripitaka, housed in the Library of the Oriental Institute in Prague, New Delhi 1978, 2002.

6. Tibetan books and newspapers (Chinese collection): with bibliographical notes, Wiesbaden-Prague 1978.

7. Ferdinand Stoliczka (1838-1874): the life and work of the Czech explorer in India and High Asia, Wien 1982.

8. The Ambans and Assistant Ambans of Tibet (A chronological study), Prague 1994. 